\section{Compost for Nitrogen Fertility Management of Bell Pepper in a Drip-irrigated Plasticulture System}

\author{
Kamyar Aram and Anusuya Rangarajan ${ }^{1}$ \\ Department of Horticulture, Cornell University, Ithaca, NY 14853
}

Additional index words. organic amendments, nitrogen mineralization, plastic mulch, fertigation

\begin{abstract}
Two types of commercial compost produced from manure and food waste or brewery waste solids were tested for supplying the $\mathrm{N}$ requirements of a bell pepper crop in a drip-irrigated plasticulture system over two seasons. Composts were tested at 40 and 80 $\mathrm{Mg} \cdot \mathrm{ha}^{-1}$, and combined with 67 and 133 or 0 and $67 \mathrm{~kg} \cdot \mathrm{ha}^{-1} \mathrm{~N}$ applied as mineral fertilizer in the first and second seasons, respectively. Both types of compost increased total soil carbon and $\mathrm{N}$ content relative to unamended soil. Compost amendment also increased soil $\mathrm{NO}_{3}-\mathrm{N}, \mathrm{NH}_{4}-\mathrm{N}$ and $\mathrm{N}$ mineralization potential throughout the season, but yields were not affected. Increasing compost amendment rate from 40 to $80 \mathrm{Mg} \cdot \mathrm{ha}^{-1}$ did not increase $\mathrm{N}$ levels in soil or plants. Yield was not affected and season biomass accumulation was inconsistently affected by compost amendment. Commercial composts thus released mineral $\mathbf{N}$ in the first year of application, but supplementation with mineral fertilizer may be necessary depending on seasonal variation of $\mathrm{N}$ release and crop need.
\end{abstract}

Compost, when applied to soil, can serve as a source of nutrients as microbial decomposition of compost organic matter releases mineral nutrients (Dick and McCoy, 1993). The percentage of total compost nitrogen $(\mathrm{N})$ that is mineralized and becomes available for plant uptake within a growing season varies greatly depending partly on the properties of the compost, its parent material, carbon (C) to $\mathrm{N}$ ratio, and time elapsed after amendment (Dick and McCoy, 1993). Estimations in the literature for the mineralization of total compost organic $\mathrm{N}$ within the first year of amendment to soil range from $\mathrm{N}$ immobilization to $25 \%$ mineralization from composts made from urban and municipal wastes, yard wastes, sewage sludge (biosolids), food residuals, and manures (Dick and McCoy, 1993; Eghball, 2000; Hadas and Portnoy, 1994; Hartz et al., 2000; Hartz and Giannini, 1998; He et al, 2000; Paul and Beauchamp, 1994; Sikora and Enkiri, 2000; Sullivan et al., 2002). The wide range of methodologies used in obtaining these values makes it difficult to interpret the results together. However, these studies generally suggest that the slow short-term release of $\mathrm{N}$ from composts requires supplementation with mineral fertilizer to sustain optimal levels for plant growth.

The physical, chemical and biological changes brought about in soil by compost amendment can also have consequences for

\footnotetext{
Received for publication 25 Aug. 2004. Accepted for publication 21 Sept. 2004. This paper is a portion of a thesis submitted by K. Aram as partial fulfillment of the requirements of the degree of Master of Science. Mention of a trademark, proprietary product, or vendor does not constitute a guarantee or warranty of the product, and does not imply its approval to the exclusion of other products or vendors that also may be suitable

${ }^{1}$ Associate professor, to whom reprint requests should be addressed; e-mailar47@cornell.edu.
}

availability and uptake of nutrients added as mineral fertilizers. Sikora and Enkiri (2000) observed higher yields when biosolids compost-ammonium nitrate blends were used to deliver the sufficient rate of $\mathrm{N}$ to fescue (Festuca arundinacea Schreb.) than when fertilizer alone was used. They concluded that fertilizer stimulated compost $\mathrm{N}$ mineralization.

Vegetable production systems are particularly suited to the use of compost, due to high value of crops, intensity of production, and use of unique growing strategies, such as raised beds with plastic mulch and drip irrigation. Commercially available composts derived from animal manures and various food wastes, including those from food processing, are now available in northeastern U.S. Such products may be attractive to vegetable producers because of improved consistency, quality, and volume available. The objectives of this research were 1) to determine if locallyproduced composts from manure and food waste or brewery waste could supply part or all of the $\mathrm{N}$ requirements for the growth and yield of a bell pepper crop in the plasticulture system in which it is typically grown in the Northeast; 2) to determine if two rates of these composts and different rates of mineral $\mathrm{N}$ fertilizer had an interactive effect on crop yield; and 3) to examine the soil and plant $\mathrm{N}$ dynamics of the system at important pepper crop growth stages.

\section{Materials and Methods}

Experiments were conducted in 2000 and 2001 at Cornell University's Homer Thompson Vegetable Research Farm, Freeville, N.Y., on a Howard gravelly loam soil (loamy-skeletal mixed semic Glossoboric Hapludalf). Soil chemical characteristics are shown in Table 1. The fields were selected for low nitrogen fertilization history. Phosphorus $\left(59 \mathrm{~kg} \cdot \mathrm{ha}^{-1}\right)$ and potassium $\left(111 \mathrm{~kg} \cdot \mathrm{ha}^{-1}\right)$ were broadcast and incorporated into the soil of the experiment site prior to applying compost and forming beds each year. No $\mathrm{N}$ fertilizer was pre-applied. The crop was grown on raised beds covered with black plastic mulch, with drip irrigation.

Treatments consisted of selected combinations of compost type, compost rate and level of mineral N fertilization (Table 2). Treatments not amended with compost (unamended) served as controls. The composts evaluated were made using either brewery waste solids (BC) (Commodity Specialists, Baldwinsville, N.Y.) or dairy cow manure and preconsumer supermarket food wastes (MFC) (Toad Hollow Farms, Nedrow, N.Y.). Chemical analyses for composts are shown in Table 3. Compost application rates of 40 and $80 \mathrm{Mg} \cdot \mathrm{ha}^{-1}$ (dry matter) were designated to deliver half $\left(67 \mathrm{~kg} \cdot \mathrm{ha}^{-1}\right)$ or all, respectively, of the $133 \mathrm{~kg} \cdot \mathrm{ha}^{-1}$ recommended fertilization rate for this crop (Reiners et al., 2000). These compost rates were based on an estimated $10 \%$ expected mineralization of total N content (Eghball, 2000; Hadas and Portnoy, 1994). Fertilization with mineral N was at 67 and $133 \mathrm{~kg} \cdot \mathrm{ha}^{-1}$ in 2000 , corresponding to half and all the recommended fertilizer rate for peppers, respectively, and at 0 and 67 $\mathrm{kg} \cdot \mathrm{ha}^{-1}$ in 2001 (Table 2). Mineral N fertiliza-

Table 1. Percent organic matter $(\mathrm{OM})$ by combustion and $\mathrm{pH}$ and nutrient analyses by Morgan's Extraction Method of unamended soil of experiment sites at the beginning of each season.

\begin{tabular}{lcccccccccc}
\hline & & \multicolumn{7}{c}{ OM } & \multicolumn{7}{c}{ Available nutrient $\left(\mathrm{mg} \cdot \mathrm{kg}^{-1}\right)$} \\
\cline { 5 - 10 } Season & $\mathrm{pH}$ & $(\%)$ & $\mathrm{P}$ & $\mathrm{K}$ & $\mathrm{Ca}$ & $\mathrm{Mg}$ & $\mathrm{Fe}$ & $\mathrm{Mn}$ & $\mathrm{Zn}$ & $\mathrm{Al}$ \\
\hline 2000 & 6.5 & 4.0 & 12 & 143 & 135 & 1835 & 2 & 18 & 1 & 24 \\
2001 & 5.9 & 3.5 & 21 & 293 & 165 & 1560 & 3 & 24 & 3 & 30 \\
\hline
\end{tabular}

Table 2. Seasons in which treatments selected from factorial of compost type, rate, and fertilizer $\mathrm{N}$ rate were tested. Compost types were manure-food waste (MFC) and brewery waste solids (BC).

\begin{tabular}{lccccc}
\hline & \multicolumn{5}{c}{ Compost type } \\
\cline { 2 - 6 } Supplemental & None & \multicolumn{5}{c}{ Compost rate $\left(\mathrm{Mg} \cdot \mathrm{ha}^{-1}\right)$} \\
\cline { 2 - 6 } $\begin{array}{l}\text { mineral N } \\
\left(\mathrm{kg} \cdot \mathrm{ha}^{-1}\right)\end{array}$ & 0 & 40 & \multicolumn{5}{c}{ Years tested } \\
\hline 0 & 2001 & 2001 & 2001 & 2001 & 2001 \\
67 & 2000,2001 & 2000,2001 & 2000,2001 & 2000,2001 & 2000,2001 \\
133 & 2000,2001 & --- & 2000 & 2000 & 2000 \\
200 & 2001 & --- & --- & -- & - \\
\hline
\end{tabular}


Table 3. Percent C, N, and organic matter (OM) by combustion, and nutrient analysis by Morgan's Extraction method of manure-food waste (MFC) and brewery waste solids (BC) composts used in each season.

\begin{tabular}{|c|c|c|c|c|c|c|c|c|c|c|c|c|c|}
\hline \multirow[b]{2}{*}{ Compost } & \multirow[b]{2}{*}{ Season } & \multirow{2}{*}{$\begin{array}{c}\mathrm{N} \\
(\%)\end{array}$} & \multirow{2}{*}{$\begin{array}{c}\mathrm{C} \\
(\%)\end{array}$} & \multirow{2}{*}{$\begin{array}{c}\mathrm{C} \text { to } \mathrm{N} \\
\text { ratio }\end{array}$} & \multirow[b]{2}{*}{$\mathrm{pH}$} & \multirow{2}{*}{$\begin{array}{l}\mathrm{OM} \\
(\%)\end{array}$} & \multicolumn{7}{|c|}{ Available nutrient $\left(\mathrm{mg} \cdot \mathrm{kg}^{-1}\right)$} \\
\hline & & & & & & & $\mathrm{P}$ & $\mathrm{K}$ & $\mathrm{Ca}$ & $\mathrm{Mg}$ & $\mathrm{Fe}$ & $\mathrm{Mn}$ & $\overline{\mathrm{Zn}}$ \\
\hline$\overline{\mathrm{BC}}$ & 2000 & 1.8 & 34 & 19 & 6.0 & 76.6 & 216 & 1788 & 6853 & 1632 & 131 & 71 & 58 \\
\hline & 2001 & 1.3 & 32 & 25 & 6.5 & 54.0 & 217 & 1280 & 3275 & 1320 & 114 & 78 & 14 \\
\hline $\mathrm{MFC}$ & 2000 & 1.8 & 18 & 10 & 7.9 & 27.6 & 943 & 3497 & 19622 & 1879 & 20 & 80 & 6 \\
\hline & 2001 & 1.1 & 15 & 14 & 8.3 & 17.8 & 343 & 4475 & 15395 & 1318 & 15 & 105 & 9 \\
\hline
\end{tabular}

tion levels used in combination with composts were lowered in 2001 based on yield results from 2000. Unamended treatments fertilized at 133 and $200 \mathrm{~kg} \cdot \mathrm{ha}^{-1} \mathrm{~N}$ were included to determine the upper $\mathrm{N}$ fertility limit of the crop (Table 2).

Compost was spread manually onto the surface of the plot areas on 9 and 12 June 2000 and on 16 May 2001. Plastic mulch-covered beds $0.76 \mathrm{~m}$ wide and $8 \mathrm{~cm}$ high were formed on 16 June in 2000 and on 17 May in 2001. About 8-week-old pepper seedlings ('Boynton Bell', Harris Seeds, Rochester, N.Y.) were transplanted into the beds in two staggered rows with $0.38 \mathrm{~m}$ spacing between plants within and between rows. Transplanting was on 19 June 2000 and on 5 June 2001.

The total mineral $\mathrm{N}$ for each treatment was delivered with liquid fertilizer (urea-ammonium nitrate with ammonium thiosulfate, $30 \%$ N, Nutrite Corp.-Liquid Products Division, Waterloo, N.Y.) through drip irrigation lines (fertigation) in equal increments over the season. Each plot could be fertigated selectively. Irrigation lines were filled prior to commencing the application of fertilizer and irrigation was continued afterwards to ensure complete delivery. In 2000, all full-rate N fertilizer treatments were fertigated with 22.2 $\mathrm{kg} \cdot \mathrm{ha}^{-1} \mathrm{~N}$ on 30 June, 21 July, 1, 10, and 24 Aug., and 1 Sept. (11, 32, 43, 52, 66, and 74 days after transplanting, DAP). Half-rate $\mathrm{N}$ fertilizer treatments were fertigated with the same amount of fertilizer $\mathrm{N}$ commencing on the same date, but only every-other date thereafter. In 2001, all fertigations were delivered on 11 and 25 June, 9 and 19 July, and 3 and 15 Aug. $(6,20,34,44,59$, and 72 DAP) with 11.1 , 22.2 , and $33.3 \mathrm{~kg} \cdot \mathrm{ha}^{-1} \mathrm{~N}$ for the 67,133 , and $200 \mathrm{~kg} \cdot \mathrm{ha}^{-1} \mathrm{~N}$ treatments, respectively. Nonfertilized treatments were irrigated on the same dates with an amount of water comparable to that required for delivery of fertilizer.

Weeds were controlled between rows by hand cultivation after initial applications of metolachlor (Dual Magnum, Syngenta Crop Protection, Inc., Greensboro, N.C.) on 20 June 2000 and 31 May 2001. European corn borer [Ostrinia nubilalis (Hübner)], was monitored using 'Heliothis' (cone vinyl mesh) traps with pheromone lures (Scentry Biologicals, Inc., Billings, Mont.). Insecticides were applied when counts were above threshold: acephate (Orthene 75S, Valent, USA, Inc., Richardson, Texas) on 17 Aug. 2000, and permethrin (Ambush, Syngenta Crop Protection, Inc., Greensboro, N.C.) on 2 and 8 Aug. 2001. For control of Aphids, imidacloprid (Provado, Bayer Corp., Kansas City, Mo.) and endosulfan (Thiodan 3 EC; FMC Corp., Philadelphia, Pa.) were applied on 5 July 2000 and 27 June 2001, respectively. Soil moisture was monitored by measure of electrical conductivity through gypsumblocks (relative indication of soil water suction) inserted $15 \mathrm{~cm}$ deep into a selection of plots representing all compost type treatments. Irrigation was applied to maintain conductance above $90 \%(100 \%$ conductance $=$ saturation $)$. Soil moisture levels were generally similar for unamended and compost treatments. Soil and surface temperatures of beds were monitored by HOBO temperature loggers (Onset Computer Corp., Pocasset, Mass.) from the time of transplanting until mid-August.

Randomized complete block design was used (compost type, rate, and mineral $\mathrm{N}$ level) with four replications. Plots were $4.9 \mathrm{~m}$ long and all data were taken from the center $3.1 \mathrm{~m}$ of each plot, including 16 plants. Soils were sampled to a $15 \mathrm{~cm}$ depth from the data area in each plot on 22 June, 31 July and 17 Aug. (3, 42, and 59 DAP) 2000, and on 4 June, 2 and 24 July (-1, 27 and 49 DAP) 2001 . These dates corresponded with time of transplanting, start of flower set, and fruit bulking of the crop. Soil samplings were timed to allow reasonable time in light of irrigation and precipitation events for fertigated $\mathrm{N}$ to be taken up or leached out in order to avoid confounding soil and compost N. Soil samples were sieved to remove particles larger than $2 \mathrm{~mm}$ in diameter. Subsamples from the first soil sampling of each season were ground and evaluated by combustion for total percentage of $\mathrm{C}$ and $\mathrm{N}$ (NC $2100 \mathrm{C}$ and $\mathrm{N}$ analyzer, CE Instruments, Rodano, Italy) to determine effect of compost amendment. Three replicate subsamples (about $8 \mathrm{~g}$ ) of all soil samples were extracted with $2.0 \mathrm{M} \mathrm{KCl}$ following standard methods (Allan and Killorn, 1996) for analysis of $\mathrm{NO}_{3}-\mathrm{N}$ and $\mathrm{NH}_{4}-\mathrm{N}$ (Technicon AutoAnalyzer System I, Terrytown, N.Y.). Nitrogen mineralization potential of soil samples was estimated using the 7-d anaerobic incubation method of Drinkwater et al. (1996). Briefly, on the same day as extractions for $\mathrm{NO}_{3}-\mathrm{N}$ and $\mathrm{NH}_{4}-\mathrm{N}$ were performed, about $8 \mathrm{~g}$ soil was placed into a $50 \mathrm{~mL}$ centrifuge tube with $10 \mathrm{~mL}$ deionized water. The air in the tube was purged with $\mathrm{N}_{2}$ gas, and the tube was sealed with a rubber stopper (\#6) and secured with electrical tape. The tubes were incubated for $7 \mathrm{~d}$ at $30^{\circ} \mathrm{C}$, after which they were extracted with $30 \mathrm{~mL} 2.67$ $\mathrm{M} \mathrm{KCl}$ and analyzed for $\mathrm{NH}_{4}-\mathrm{N}$ as described above. The difference in level of $\mathrm{NH}_{4}-\mathrm{N}$ in incubated samples and those extracted at the start of the incubation was used as an estimate of potentially mineralizable $\mathrm{N}$.

A composite of 30 most recently matured leaves were collected from data-area plants of each plot concurrent with the 2 nd and 3 rd soil samplings, as well as after the final harvest, 27
Sept. (100 DAP) in 2000, and 15 Sept. (102 DAP) in 2001. Leaf samples were rinsed three times with tap water, excess water removed by blotting, and forced-air dried at $70{ }^{\circ} \mathrm{C}$. Dried tissue was ground ( 30 mesh, $0.52 \mathrm{~mm}$ pore size), and three 0.2 -g subsamples were extracted in $20 \mathrm{~mL}$ deionized water. Leaf $\mathrm{NO}_{3}$ $\mathrm{N}$ concentration was determined as follows (Cataldo et al., 1975): $0.2 \mathrm{~mL}$ aliquot of each solution was added to $1 \mathrm{~mL}$ of a $10 \%(\mathrm{w} / \mathrm{v})$ salicylic acid in $96 \%$ sulfuric acid $\left(\mathrm{H}_{2} \mathrm{SO}_{4}\right)$, and $20 \mathrm{~mL} 2.0 \mathrm{~N}$ sodium hydroxide $(\mathrm{NaOH})$ were added after exactly $20 \mathrm{~min}$. After cooling for at least $20 \mathrm{~min}$, the absorbance of the resulting solution was measured at $410 \mathrm{~nm}$ with a spectrophotometer(UV-1601; Shimadzu Corp., Kyoto, Japan). The nitrate concentration was determined in relation to a standard curve prepared the same day.

Yield of green fruit of marketable size was evaluated over seven harvests of 4 to 7-d intervals, beginning on 24 Aug. 2000 and 15 Aug. 2001, respectively. Fruit were graded by weight into marketable categories of small (113 to $149 \mathrm{~g}$ ), medium (150 to $224 \mathrm{~g}$ ), and large $(>225 \mathrm{~g})$, and defective fruit or those weighing $<113 \mathrm{~g}$, were categorized as culls. Fruit number and total weight for each category were recorded on each date.

After the final harvest, the aboveground growth of five whole plants were removed from each plot and dried in a greenhouse to determine average per plant aboveground biomass.

All data were subjected to analysis of variance using the general linear model (GLM) protocol in SAS statistical software (SAS, Inc., Cary, N.C.). When required, data were transformed using either an inverse or a natural logarithm to normalize variances prior to analysis. Re-transformed results are presented. Means were differentiated using least significant difference (LSD) at $P<0.05$. Since the lack of a rate factor for unamended treatments caused an incongruity for threeway factorial analysis, in order to include unamended treatments in analyses of soil data including compost rate, factorials of compost type and compost rate were combined as individual treatments of compost type and rate for those analyses. Unamended treatments fertilized with mineral $\mathrm{N}$ rates of 133 and 200 $\mathrm{kg} \cdot \mathrm{ha}^{-1}$ in 2001 were not included in analyses with compost treatments, but were included in analyses of all unamended controls.

\section{Results and Discussion}

Crop response. A combined analysis of treatments repeated in both seasons indicated a significant interaction by year $(P<0.0001)$ for of all plant variables measured; hence, data 
Table 4. Effect of manure-food waste (MFC) and brewery waste solids (BC) compost amendment and $\mathrm{N}$ fertilizer addition on pepper dry shoot biomass, leaf $\mathrm{N}$ levels, and fruit yield for 2000 season. $^{\mathrm{z}}$

\begin{tabular}{|c|c|c|c|c|c|c|c|}
\hline \multirow[b]{3}{*}{ Parameter } & \multirow{3}{*}{$\begin{array}{c}\text { Dry shoot } \\
\text { biomass } \\
\text { (g/plant) }\end{array}$} & \multirow{2}{*}{\multicolumn{3}{|c|}{ Leaf $\mathrm{NO}_{3}-\mathrm{N}\left(\mathrm{mg} \cdot \mathrm{kg}^{-1}\right)$}} & \multicolumn{3}{|c|}{ Marketable yield } \\
\hline & & & & & \multicolumn{2}{|c|}{ Per plant } & \multirow{2}{*}{$\begin{array}{c}\text { Per ha } \\
\mathrm{Mg}\end{array}$} \\
\hline & & Flower $^{x}$ & Fruit & Season end & no. & $\mathrm{kg}$ & \\
\hline \multicolumn{8}{|l|}{ Compost type } \\
\hline No compost & $45.8 b^{w}$ & 1770 & 879 & 672 & 7.01 & 1.25 & 22.4 \\
\hline $\mathrm{BC}$ & $51.0 \mathrm{a}$ & 2098 & 985 & 809 & 6.69 & 1.22 & 21.9 \\
\hline $\mathrm{MFC}$ & $46.1 \mathrm{~b}$ & 2003 & 902 & 878 & 6.99 & 1.21 & 21.6 \\
\hline$p$ value & 0.0402 & NS & NS & NS & NS & NS & \\
\hline \multicolumn{8}{|c|}{$\mathrm{N}$ fertilizer $\left(\mathrm{kg} \cdot \mathrm{ha}^{-1}\right)$} \\
\hline 67 & 45.0 & 1768 & 892 & 794 & 6.63 & 1.19 & 21.3 \\
\hline 133 & 50.2 & 2146 & 952 & 779 & 7.16 & 1.26 & 22.6 \\
\hline$p$ value & 0.0123 & 0.0152 & NS & NS & NS & NS & \\
\hline
\end{tabular}

${ }^{\mathrm{z}}$ Compost rate and all interactions not significant and not shown.

y 17,940 plants/ha.

${ }^{x}$ Flower set (flower), fruit bulking (fruit), and final harvest (season end) leaf sampling times 31 July, 17 Aug., and 27 Sept. (42, 59, and 100 DAP).

${ }^{w}$ Mean separation within columns for compost or fertilizer $\mathrm{N}$ by least significant difference at $P<0.05$.

Table 5. Effect of manure-food waste (MFC) and brewery waste solids (BC) compost amendment and $\mathrm{N}$ fertilizer addition on pepper dry shoot biomass, leaf $\mathrm{N}$ levels, and fruit yield for 2001 season. ${ }^{2}$

\begin{tabular}{|c|c|c|c|c|c|c|c|}
\hline \multirow[b]{3}{*}{ Parameter } & \multirow{3}{*}{$\begin{array}{l}\text { Dry shoot } \\
\text { biomass } \\
\text { (g/plant) }\end{array}$} & \multirow{2}{*}{\multicolumn{3}{|c|}{ Leaf $\mathrm{NO}_{3}-\mathrm{N}\left(\mathrm{mg} \cdot \mathrm{kg}^{-1}\right)$}} & \multicolumn{3}{|c|}{ Marketable yield } \\
\hline & & & & & \multicolumn{2}{|c|}{ Per plant } & \multirow{2}{*}{$\begin{array}{c}\text { Per ha } \\
\text { Mg }\end{array}$} \\
\hline & & Flower $^{x}$ & Fruit & Season end & no. & $\mathrm{kg}$ & \\
\hline \multicolumn{8}{|l|}{ Compost type } \\
\hline No compost & 80.1 & 2399 & $1683 a b^{w}$ & 778 & 8.99 & 1.65 & 29.6 \\
\hline $\mathrm{BC}$ & 83.2 & 2790 & $2174 \mathrm{a}$ & 741 & 8.90 & 1.61 & 28.8 \\
\hline $\mathrm{MFC}$ & 82.1 & 2534 & $1676 \mathrm{~b}$ & 794 & 9.51 & 1.71 & 30.7 \\
\hline$p$ value & NS & 0.0557 & 0.0343 & NS & NS & NS & \\
\hline \multicolumn{8}{|c|}{$\mathrm{N}$ fertilizer $\left(\mathrm{kg} \cdot \mathrm{ha}^{-1}\right)$} \\
\hline 0 & 80.4 & 2448 & 1655 & 731 & 9.28 & 1.66 & 29.9 \\
\hline 67 & 83.2 & 2700 & 2034 & 813 & 8.98 & 1.65 & 29.6 \\
\hline$p$ value & NS & NS & 0.0503 & NS & NS & NS & \\
\hline \multirow{2}{*}{\multicolumn{8}{|c|}{$\begin{array}{l}\text { Unamended controls }{ }^{\mathrm{v}} \\
\mathrm{N} \text { fertilizer }\left(\mathrm{kg} \cdot \mathrm{ha}^{-1}\right)\end{array}$}} \\
\hline & & & & & & & \\
\hline 0 & 74.5 & 2208 & $1712 \mathrm{~b}$ & $764 \mathrm{~b}$ & 9.23 & 1.69 & 30.4 \\
\hline 67 & 83.2 & 2590 & $1655 \mathrm{~b}$ & $792 \mathrm{~b}$ & 8.74 & 1.61 & 28.8 \\
\hline 133 & 90.0 & 2511 & $2718 \mathrm{a}$ & $859 \mathrm{~b}$ & 9.58 & 1.77 & 31.8 \\
\hline 200 & 81.1 & 2512 & $2810 \mathrm{a}$ & $1403 \mathrm{a}$ & 8.90 & 1.61 & 28.8 \\
\hline$p$ value & NS & NS & 0.0038 & 0.0176 & NS & NS & \\
\hline
\end{tabular}

${ }^{\mathrm{z}}$ Compost rate and all interactions not significant except as noted in text.

y 17,940 plants/ha.

xFlower set (flower), fruit bulking (fruit) and final harvest (season end) leaf sampling times 2 and 24 July, and 15 Sept. (27, 49, and 102 DAP).

${ }^{w}$ Mean separation within columns for compost or fertilizer $\mathrm{N}$ by least significant difference at $p<0.05$

${ }^{\mathrm{v}}$ Analysis includes treatments not amended with compost only.

are presented by year. One reason for this difference was that high wind and precipitation contributed to late transplanting and poor early season plant establishment in 2000 compared to 2001. Rainfall in the months of May, June and July 2000 totaled $14.1,15.2$, and $7.8 \mathrm{~cm}$, respectively, and in 2001, 6.8, 11.2, and 5.1, respectively. Also, average temperatures were higher in 2001 than 2000. The 2000 season was mild and average daily soil temperatures ranged from 20 to $24{ }^{\circ} \mathrm{C}$ with an average of $22{ }^{\circ} \mathrm{C}$. Growing season soil temperatures in 2001 were more variable, ranging from 18 to $27{ }^{\circ} \mathrm{C}$, with average daily soil temperatures of 24,22 , and $25^{\circ} \mathrm{C}$ in June, July, and early August, respectively.

Dry shoot biomass was higher with $\mathrm{BC}$ than MFC or unamended in 2000 (Table 4), but no difference occurred among compost treatments in 2001 (Table 5). Effects of compost amendment on crop biomass have been variable, with increase(Ozores-Hampton etal., 1994), no effect (Hartz et al., 1996; OzoresHampton et al., 1994) and decrease (Clark et al., 2001) reported, indicating that the effect depends on the particular material and context of use. Higher N fertilizer rate $\left(133 \mathrm{~kg} \cdot \mathrm{ha}^{-1}\right)$ in
2000 also increased shoot dry biomass (Table 4). In 2001 (Table 5), no fertilizer rate effects were observed.

Leaf $\mathrm{NO}_{3}-\mathrm{N}$ results (Tables 4 and 5) confirmed previous reports that pepper leaf $\mathrm{N}$ concentration drops considerably in the transition from the vegetative to the reproductive stage of crop growth, suggesting remobilization of foliar N into fruit (Hartz et al., 1993; Locascio et al., 1981; Panpruik et al., 1982; Stroehlein and Oebker, 1979). Pepper leaf N levels have generally responded positively to $\mathrm{N}$ fertilization during fruit development, even when there was no effect on yield (Batal and Smittle, 1981; Hartzet al., 1993; Locascio etal., 1981; O'Sullivan, 1979; Panpruik et al., 1982; Simonne et al., 1998; Stroehlein and Oebker, 1979). In this study, a positive leaf $\mathrm{NO}_{3}-\mathrm{N}$ response to compost or mineral $\mathrm{N}$ fertilization occurred only in 2001 (Tables 4 and 5), suggesting factors other than availability limited $\mathrm{N}$ uptake in 2000. This is further supported by the fact that in 2000 leaf $\mathrm{NO}_{3}-\mathrm{N}$ levels during fruit bulking for all treatments were slightly below the $1000 \mathrm{mg} \cdot \mathrm{kg}^{-1}$ suggested sufficiency (Panpruik et al., 1982; Stroehlein and Oebker, 1979) while they were well above this level in 2001 (Tables 4 and 5). Greater biomass accumulation and yield in 2001 compared to 2000 also highlight the seasonal effect on crop growth.

Effect of compost type was not significant for leaf $\mathrm{NO}_{3}-\mathrm{N}$ at the end of season samplings in either year, but in 2001 there was a significant compost rate $\times$ mineral $\mathrm{N}$ rate interaction $(P=$ $0.0318)$. The high rate of compost $\left(80 \mathrm{Mg} \cdot \mathrm{ha}^{-1}\right)$ with no $\left(0 \mathrm{~kg} \cdot \mathrm{ha}^{-1}\right)$ fertilizer $\mathrm{N}$ added resulted in significantly lower leaf $\mathrm{NO}_{3}-\mathrm{N}\left(615 \mathrm{mg} \cdot \mathrm{kg}^{-1}\right)$ than the high compost rate with $67 \mathrm{~kg} \cdot \mathrm{ha}^{-1}$ fertilizer $\mathrm{N}$ (leaf $\mathrm{NO}_{3}-\mathrm{N} 880 \mathrm{mg} \cdot \mathrm{kg}^{-1}$ ) or the low rate of compost $\left(40 \mathrm{Mg} \cdot \mathrm{ha}^{-1}\right)$ without fertilizer (leaf $\mathrm{NO}_{3}-\mathrm{N} 846 \mathrm{mg} \cdot \mathrm{kg}^{-1}$ ). The low compost rate with $67 \mathrm{~kg} \cdot \mathrm{ha}^{-1}$ fertilizer $\mathrm{N}\left(786 \mathrm{mg} \cdot \mathrm{kg}^{-1}\right.$ leaf $\mathrm{NO}_{3}-\mathrm{N}$ ) did not significantly differ from any other treatment. This suggests that the high rate of compost resulted in $\mathrm{N}$ immobilization late in the season, but that supplementation with Mineral N compensated for this effect. Though lower N uptake was inconsequential to the crop at this time, this suggests that potential periods of $\mathrm{N}$ immobilization can be corrected with supplementation with mineral $\mathrm{N}$.

Yield of pepper ranged from 21.3 to 31.8 $\mathrm{Mg} \cdot \mathrm{ha}^{-1}$ and were comparable to other yield re- 
ports in the Northeast(O'Sullivan, 1979). There were no differences in marketable yield due to compost or fertilizer $\mathrm{N}$ treatments (Tables fertilization has frequently been reported for 1979; Panpruik et al., 1982; Stroehlein and Oebker, 1979). O'Sullivan(1979) reported that pepper yield in Ontario did not significantly and that in three of four seasons yields were maintained without the addition of $\mathrm{N}$ fertilizer. Positive yield response to $\mathrm{N}$ has been reported mainly in warmer climates, with rates ranging between 140 to $252 \mathrm{~kg} \cdot \mathrm{ha}^{-1} \mathrm{~N}$ (Batal and Smittle, 1981; Hartz et al., 1993; Locascio et al., 1981; Simonne et al., 1998).

Studies on the $\mathrm{N}$ requirements of pepper have indicated that moderate to low $\mathrm{N}$ supply during vegetative growth favors early fruit set, while the highest $\mathrm{N}$ requirement for pep4 and 5). Lack of yield response to nitrogen pepper (Bowen and Frey, 2002; O'Sullivan, respond to $\mathrm{N}$ fertilization above $70 \mathrm{~kg} \cdot \mathrm{ha}^{-1}$,

pers occurs during fruit development (Marti and Mills, 1991; Hartz et al., 1993; Xu et al., 2001). Xu et al. (2001) found that excessive $\mathrm{N}$ supply during vegetative growth more critically limited final yield under cool and light-limited growing conditions when yield was spread out over a greater number of days than under warmer and light-optimal conditions. Higher $\mathrm{N}$ rates are also required to support a greater number of harvests (Marti and Mills, 1991; Simonne et al., 1998; Panpruik et al., 1982; Stroehlein and Oebker, 1979). Therefore, the $\mathrm{N}$ requirement of a pepper crop occurs at the time of fruit development and depends on the duration and intensity of fruit harvesting. The results of this study confirm that lower $\mathrm{N}$ rates $\left(<67 \mathrm{~kg} \cdot \mathrm{ha}^{-1)}\right.$ may be sufficient for pepper in cooler climates, where factors other than $\mathrm{N}$ availability may limit yield.

Soil measurements. The interactions of season and soil measurements were significant

Table 6. Effect of manure-food waste (MFC) and brewery waste solids (BC) compost amendment at 40 or $80 \mathrm{Mg} \cdot \mathrm{ha}^{-1}$ on soil carbon and nitrogen properties sampled at transplanting, 2000 and 2001.

\begin{tabular}{llccc}
\hline \multirow{2}{*}{ Season } & \multicolumn{2}{l}{$\begin{array}{l}\text { Compost type and } \\
\text { rate }(\mathrm{C})^{\mathrm{z}}\left(\mathrm{Mg} \cdot \mathrm{ha}^{-1}\right)\end{array}$} & Soil C & Soil N \\
\cline { 3 - 4 } 2000 & Unamended & & $\%$ \\
& BC & 40 & $2.57 \mathrm{c}^{\mathrm{y}}$ & $0.21 \mathrm{c}$ \\
& BC & 80 & $4.47 \mathrm{~b}$ & $0.31 \mathrm{~b}$ \\
& MFC & 40 & $6.25 \mathrm{a}$ & $0.46 \mathrm{a}$ \\
& MFC & 80 & $4.77 \mathrm{ab}$ & $0.39 \mathrm{ab}$ \\
& $p$ value & & $6.70 \mathrm{a}$ & $0.52 \mathrm{a}$ \\
2001 & Unamended & & $<0.0001$ & $<0.0001$ \\
& BC & 40 & $2.24 \mathrm{c}$ & $0.24 \mathrm{c}$ \\
& BC & 80 & $3.84 \mathrm{ab}$ & $0.27 \mathrm{c}$ \\
& MFC & 40 & $4.49 \mathrm{a}$ & $0.36 \mathrm{a}$ \\
& MFC & 80 & $3.28 \mathrm{~b}$ & $0.27 \mathrm{bc}$ \\
& $p$ value & & $3.85 \mathrm{ab}$ & $0.32 \mathrm{ab}$ \\
& & $<0.0001$ & 0.0370 \\
\hline
\end{tabular}

${ }^{\mathrm{z}}$ Compost type and rate analyzed as one factor to include unamended treatment in comparisons; $\mathrm{N}$ fertilizer effect and interaction with compost not significant and not shown.

y Mean separation by least significant difference at $P<0.05$ within column.
$(P<0.05)$; hence data were analyzed separately for each year (Table 6). The interaction of season with soil measurements likely resulted in part from the fact that soil samplings were performed according to the rate of crop development which varied by year. Mineral fertilizer $\mathrm{N}$ applications during the season did not affect soil $\mathrm{N}$ measurements on any sampling date in either year, indicating that fertilizer source $\mathrm{N}$ was taken up by plants, leached out of the top $15 \mathrm{~cm}$ sampling depth, or immobilized within the soil medium between fertigation and sampling times.

Compost amendment at $80 \mathrm{Mg} \cdot \mathrm{ha}^{-1}$ increased soil $\mathrm{C}$ and $\mathrm{N}$ content compared to unamended soil in both seasons (Table 6). Amendment of $40 \mathrm{Mg} \cdot \mathrm{ha}^{-1}$ compost also resulted in higher soil $\mathrm{C}$ and $\mathrm{N}$ levels relative to unamended soil in 2000, but in 2001 this rate of amendment only significantly increased soil $\mathrm{C}$ levels. This was likely due to lower compost $\mathrm{N}$ levels in 2001. In both years, increasing $\mathrm{BC}$ amendment rate from 40 to $80 \mathrm{Mg} \cdot \mathrm{ha}^{-1}$ increased soil $\mathrm{N}$ significantly but no rate effect was observed for MFC. Compost consistently increased soil $\mathrm{NO}_{3}-\mathrm{N}$ compared to unamended soil in 2000 but not 2001 (Table 7). Soil $\mathrm{NO}_{3}-\mathrm{N}$ within treatments dropped from the first to the second sampling time but did not change from the second to the third sampling in 2000 . Highest soil $\mathrm{NO}_{3}-\mathrm{N}$ levels were with $\mathrm{BC}$ at $80 \mathrm{Mg} \cdot \mathrm{ha}^{-1}$ throughout 2000, while levels in other compost treatments were generally similar. In contrast, in 2001 soil $\mathrm{NO}_{3}-\mathrm{N}$ levels in compost-amended treatments were similar to unamended soil at the transplanting and flower set samplings, and levels for each treatment did not drop from the first to the second sampling times (Table 7). At fruit bulking, soil $\mathrm{NO}_{3}-\mathrm{N}$ levels had dropped similarly for unamended

Table 7. Effect of manure-food waste (MFC) and brewery waste solids (BC) compost amendment at $40 \mathrm{or} 80 \mathrm{Mg} \cdot \mathrm{ha}^{-1}$ on soil nitrogen properties sampled at three stages of crop development (transplanting, flower set, and fruit development), 2000 and 2001.

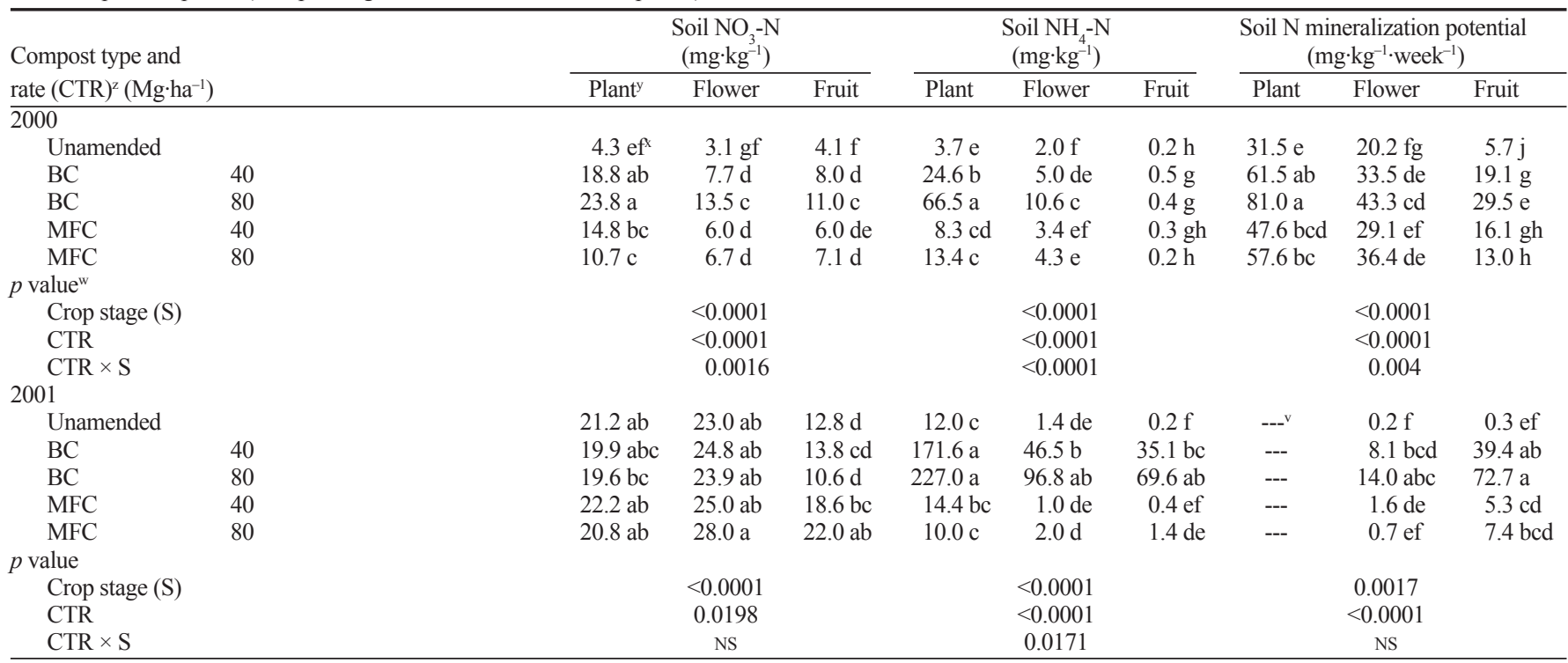

${ }^{2}$ Compost type and rate analyzed as one factor to include unamended treatment in comparisons; Nitrogen fertilizer effect and interaction with compost not significant and not shown.

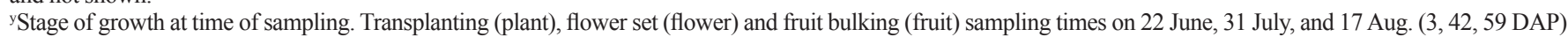
in 2000, and 4 June, 2 and 24 July (-1, 27, and 49 DAP) in 2001, respectively.

${ }^{\times}$Mean separation by least significant difference at $P<0.05$ across all three crop stages for each of NO3-N, NH4-N and N mineralization potential.

" $P$ values of analysis across sampling times placed under "Flower" column of data for each parameter.

vata not collected. 
and $\mathrm{BC}$ amended treatments but not for MFC treatments. Therefore $\mathrm{NO}_{3}-\mathrm{N}$ levels in MFCamended soils at fruit bulking were higher than the unamended soil and also higher than $\mathrm{BC}$ at $80 \mathrm{Mg} \cdot \mathrm{ha}^{-1}$. Thus, differences in composts and climatic conditions in both seasons resulted in different $\mathrm{N}$ release patterns.

Compost amendment also generally increased soil $\mathrm{NH}_{4}-\mathrm{N}$ levels relative to unamended soil in 2000 but in 2001 levels were similar in MFC amended and unamended treatments (Table 7). Soil $\mathrm{NH}_{4}-\mathrm{N}$ levels of all treatments declined over time. Amendment with $\mathrm{BC}$ resulted in very high soil $\mathrm{NH}_{4}-\mathrm{N}$ early in the season, but declined to similar levels as other treatments by the fruit bulking sampling in 2000. In 2001, soil $\mathrm{NH}_{4}-\mathrm{N}$ was again highly elevated in $\mathrm{BC}$ treatments early in the season, but in contrast to 2000 , remained very high for the subsequent sampling times.

Soil N mineralization potentials in 2000 reflected the pattern of soil $\mathrm{NH}_{4}-\mathrm{N}$ and dropped steadily over sampling times (Table 7). Soil $\mathrm{N}$ mineralization was also generally higher with compost-amended soil than unamended soil and did not generally differ between the two amendment rates. Soil N mineralization in 2001 was also generally higher with compostamended than with unamended soil, and did not differ between the two rates of compost amendment (Table 7). Significance of differences in $\mathrm{N}$ mineralization potential generally varied depending on compost rate and sampling time. In contrast to $2000, \mathrm{~N}$ mineralization rates in 2001 were higher at the fruit bulking sampling than at flower set.

Though amendment with both compost types consistently increased soil C and $\mathrm{N}$ levels, the differences in these effects between seasons highlight the variability inherent in compost material even when produced with the highly standardized materials and methods of such commercial operations, and the importance of the influence of climatic conditions and growing environment on nutrient release. Nonetheless, increases in soil $\mathrm{NO}_{3}-\mathrm{N}, \mathrm{NH}_{4}-\mathrm{N}$ and $\mathrm{N}$ mineralization potential in compost-amended compared to unamended treatments indicated that these composts released inorganic $\mathrm{N}$ during the season in both years, though the level of release also varied depending on season and sampling time.

An increase in compost application rate from 40 to $80 \mathrm{Mg} \cdot \mathrm{ha}^{-1}$ did not generally result in detectably higher soil $\mathrm{C}$ and $\mathrm{N}$ levels, although differences in soil nutrients with $\mathrm{BC}$ rates were detected. The higher levels of $\mathrm{NH}_{4}-\mathrm{N}$ that occurred in compost-amended relative to unamended treatments early in the season is in agreement with reports that $\mathrm{NH}_{4}-\mathrm{N}$ was released upon addition of composts and other organic residues to soil, and that levels diminished over time (He et al., 2000; Paul and Beauchamp, 1994). In the study of Paul and Beauchamp (1994), $\mathrm{NH}_{4}$-N levels dropped off within 3 weeks, while in the study by $\mathrm{He}$ et al. (2000) levels dropped over months and reflected the maturity and $\mathrm{C}$ to $\mathrm{N}$ ratio of the materials being tested. The high level of $\mathrm{NH}_{4}-\mathrm{N}$ with $\mathrm{BC}$ sustained throughout the 2001 season, along with its relatively high $\mathrm{C}$ to $\mathrm{N}$ ratio (Table $3)$, indicated that this compost was immature at time of application. The low $\mathrm{NO}_{3}-\mathrm{N}$ and high $\mathrm{NH}_{4}-\mathrm{N}$ levels in $\mathrm{BC}-80 \mathrm{Mg} \cdot \mathrm{ha}^{-1}$ at the fruit bulking sampling in 2001 may reflect a high microbial demand at the same time as a high pepper demand for available N. However, inorganic $\mathrm{N}$ levels were never deficient in this study. Indications of increased $\mathrm{N}$ uptake (i.e., greater biomass and leaf $\mathrm{NO}_{3}-\mathrm{N}$ ) were not consistent for compost-amended treatments and did not always reflect soil inorganic $\mathrm{N}$ levels. Also, the high levels of $\mathrm{NH}_{4}-\mathrm{N}$ measured for BC treatments did not negatively affect crop growth.

Therefore, the commercial composts tested in this study can be incorporated into this pepper plasticulture system as a source of $\mathrm{N}$ to be supplemented as needed with mineral $\mathrm{N}$ fertilizer at critical crop stages. While compost increased soil $\mathrm{N}$ levels, $\mathrm{N}$ was not the limiting factor for pepper yield in either year. Similar total season yields were achieved in this system with unamended soil fertilized with 0 to $200 \mathrm{~kg} \cdot \mathrm{ha}^{-1}$ mineral $\mathrm{N}$, even in 2001 when plants were relatively highly productive. Evaluation of pepper $\mathrm{N}$ requirements in relation to seasonal factors or other soil types of the Northeast can further improve N-use efficiency in this system. Research is needed on $\mathrm{N}$ release from compost, to improve timing of $\mathrm{N}$ supplementation. The contribution of $\mathrm{N}$ from composts should also be evaluated over multiple seasons after amendment.

\section{Literature Cited}

Allan, D.L. and R. Killorn. 1996. Assessing soil nitrogen, phosphorus, and potassium for crop nutrition and environmental risk. In: J.W. Doran and A.J. Jones (eds.). Methods for assessing soil quality. Soil Sci. Soc. Amer.Spec. Publ. 49.

Batal, K.M. and D.A. Smittle. 1981. Response of bell pepper to irrigation, nitrogen, and plant population. J. Amer. Hort. Sci. 106:259-262

Bowen, P. and B. Frey. 2002. Response of plasticultured bell pepper to staking, irrigation frequency, and fertigated nitrogen rate. Hortscience 37:95-100

Cataldo, D.A., M. Haroon, L.E. Shcrader, and V.L. Youngs. 1975. Rapid colorimetric determination of nitrate in plant tissue by nitration of salicylic acid. Commun. Soil Sci. Plant Anal. 6:71-80

Clark G.A., C.D. Stanley and D.N. Maynard. 2000. Municipal solid waste compost (MSWC) as a soil amendment in irrigated vegetable production. Trans. Amer. Soc. Agr. Eng. 43:847-853

Dick, W.A. and E.L. McCoy. 1993. Enhancing soil fertility by addition of compost. In: H.A.J. Hoitink and H.M. Keener (eds.). Science and engineering of composting: design, environmental, microbiological and utilization aspects. Renaissance, Worthington, Ohio.

Drinkwater, L.E., C.A. Cambardella, J.D. Reeder, and C.W. Rice. 1996. Potentially mineralizable nitrogen as an indicator of biologically active soil nitrogen. In: J.W. Doran and A.J. Jones (eds.). Methods for assessing soil quality. Soil Sci. Soc. Amer. Spec. Publ. 49.
Eghball, B. 2000. Nitrogen mineralization from fieldapplied beef cattle feedlot manure or compost. Soil Sci. Soc. Amer. J. 64:2024-2030

Hadas, A. and R. Portnoy. 1994. Nitrogen and carbon mineralization rates of composted manures incubated in soil. J. Envrion. Qual. 23:1184-1189

Hartz, T.K., F.J. Costa, and W.L. Schrader. 1996. Suitability of composted green waste for horticultural uses. Hortscience 31:961-964

Hartz, T.K. and C. Giannini. 1998. Duration of composting of yard wastes affects both physical and chemical characteristics of compost and plant growth. Hortscience 33:1192-1196

Hartz, T.K., M. LeStrange, and D.M. May. 1993. Nitrogen requirements of drip-irrigated peppers. Hortscience 28:1097-1099.

Hartz, T.K., J.P. Mitchell, and C. Giannini. 2000. Nitrogen and carbon mineralization dynamics of manures and composts. Hortscience 35:209-212

He, Z.L., A.K. Alva, P. Yan, Y.C. Li, D.V. Calvert, P. J. Stoffella, and D.J. Banks. 2000. Nitrogen mineralization and transformation from composts and biosolids during field incubation in a sandy soil. Soil Sci. 165:161-169

Locascio, S.J., J.G.A. Fiskell, and F.G. Martin. 1981. Responses of bell pepper to nitrogen sources. J. Amer. Soc. Hort. Sci. 106:628-632

Marti, H.R. and H.A. Mills. 1991. Nutrient uptake and yield of sweet pepper as affected by stage of development and N-form. J. Plant Nutr. 14:1165-1175

O'Sullivan, J. 1979. Response of peppers to irrigation and nitrogen. Can. J. Plant Sci. 59:1085-1091

Maynard, A.A. 1996. Cumulative effect of annual additions of undecomposed leaves and compost on the yield of field-grown peppers. Compost Sci. Util. 4:81-88

Ozores-Hampton, M., B. Schaffer, H.H. Bryan, and E.A. Hanlon. 1994. Nutrient concentrations, growth, and yield of tomato and squash in municipal solid-waste-amended soil. Hortscience 29:785-788.

Panpruik, P., B.D. McCaslin, and P.J. Wierenga. 1982. Effects of nitrogen and phosphorus fertilizer on yield and leaf content of trickle irrigated chile peppers. N.M. Agr. Expt. Sta. Res. Rpt. 480

Paul, J.W. and E.G. Beauchamp.1994. Short-term nitrogen dynamics in soil amended with fresh and composted cattle manures. Can. J. Soil. Sci. 74:147-155

Reiners, S., C.H. Petzoldt, M.P. Hoffman (eds.). 2000. Integrated crop and pest management for commercial vegetable production. Cornell Coop. Ext., Ithaca, N.Y.

Sikora L.J. and N.K. Enkiri. 2000. Efficiency of compost-fertilizer blends compared with fertilizer alone. Soil Sci. 165:444-451

Simmonne, E.H., D.J. Eakes, and C.E. Harris. 1998. Effects of irrigation and nitrogen rates on foliar mineral composition of bell pepper. J. Plant Nutr. 21:2545-2555

Stroehlein, J.L. and N.F. Oebker. 1979. Effects of nitrogen and phosphorus on yields and tissue analyses of chili peppers. Commun. Soil Sci. Plant Anal. 10:551-563

Sullivan D.M., A.I. Bary, D.R. Thomas, S.C. Fransen, and C.G. Cogger. 2002. Food waste compost effects on fertilizer nitrogen efficiency, available nitrogen, and tall fescue yield. Soil Sci. Soc. Amer. J. 66:154-161

Xu G.H., S. Wolf, and U. Kafkafi. 2001. Effect of varying nitrogen form and concentration during growing season on sweet pepper flowering and fruit yield. J. Plant Nutr. 24:1099-1116 